\title{
Partial Characterisation of Two Isolates of Cucumber mosaic virus (CMV)
}

\author{
Els ayed E. Wagih, Mohamed M. Zalat and Maha A. Kawanna* \\ Department of Plant Pathology, Faculty of Agriculture, El-Shatby, Alexandria University, Alexandria, Egypt \\ *Corresponding author: E-mail: mahakawanna@yahoo.com
}

Received on: 6-12-2020

Accepted on: 17-1-2021

\begin{abstract}
Field observation revealed that the most common symptoms on naturally infected plants in Alexandria, Dakahliya, Kafr Elsheikh and El-Beheira governorates in Egypt were severe mos aic, mild mosaic, chlorosis, mottling, vein banding, blisters, malformation, fern leaf, shoe-string and/or stunting. These symptoms were suspected of being caused by Cucumber mosaic virus (CMV) and confirmed by indirect ELISA. Two samples obtained from wild tobacco and cucumber plants reacted positively with the CMV specific antiserum. Based on symptomology and disease severity on Nicotiana glutinosa and Chenopodium amaranticolor, two isolates of CMV were named CMV-wild tobacco (from Alexandria) and CMVcucumber (from Kafr El-sheikh) and subjected to this study. Reaction of some diagnostic hosts of 11 plant species belonging to five families upon inoculation with the two isolates included different symptoms characteristic to CMVinfection, albeit those induced by CMV-wild tobacco being invariably more severe than those elicited by CMV-cucumber. Identification of virus is olates was confirmed using real time reverse transcription PCR (qRT-PCR). The test is olates demonstrated a single qRT-PCR amplification product of $500 \mathrm{bp}$. The two is olates could be transmitted mechanically and easily transmitted by four aphid species in non-persistentmanner. The most efficient vector was Myzus persicae followed by Aphis gossypii, Rhopalosiphum maidis and A. nerii with trans mis sion rates of 90\%, 70\%, 60\% and 50\%, respectively, for CMV-wild tobacco and being $80 \%, 80 \%, 40 \%$ and 30\%, res pectively for CMV-cucumber. The two is olates could not be transmitted via Cucurbita pepo seeds derived frominfected plants. However, virus infection had a great effect on seed germination.
\end{abstract}

KEYWORDS: CMV, qRT-PCR, ELISA, aphids, mode of transmission.

\section{INTRODUCTION}

Cucumber mosaic virus (CMV) is the type member of the genus Cucumovirus, family Bromoviridae (ICTV*, 2014). CMV is one of the most devastating plant viruses with probably the broadest host range for a known virus (Duarte et al., 2013). Its host range extends to more than 1,200 plant species belonging to over 100 families of dicotyledonous and monocotyledonous angiosperms (Lu et al., 2012).

In Egypt, CMV was isolated from: bean (Mazyad et al., 1974; El-Kady et al., 1979); cowpea (Morsy, 1979); Nicotiana glauca (Eid et al., 1984); pepper (Abu Foul, 1989); cucumber (Fegla and El Mazaty, 1981; Megahed et al., 2012); Banana; Geranium and Gladiolus (El-dougdoug et al., 2013). It was also isolated in other countries from different plants such as Turkey from Parsley (Sevik and Akcura, 2011); Syria from Potato (Chikh Ali et al., 2012); Malaysia from Catharanthus roseus (Mazidah et al., 2012); India from Tomato (Pratap et al., 2012); Korea from Capsicum annuum var. grossum (Kim et al., 2002),
Zea mays (Kim et al., 2011) and Vigna angularis var. nipponensis (Kim et al., 2014).

The characteristic field symptoms of CMV disease include stunting of plants, yellowing (chlorosis), mottling, extreme filiform or shoestring of leaves, depending on virus strain and the host (Carrere et al., 1999; Sulistyowati et al., 2004).

CMV is spread primarily by aphids, cucumber beetles, humans (during cultivation and handling of affected plants) also by experimental mechanical inoculation with an infectious sap (Francki et al., 1979). Mechanical transmission is considered to be the most important method for CMV-transmission. Transmission of CMV via seeds has been reported in several plant species, with efficiencies varying from less than $1 \%$ to up to $50 \%$ (Garcia-Arenal and Palukaitis, 2008).

The aim of the present investigation was to isolate and characterise the virus isolates based mainly on the reaction of diagnostic hosts and symptomology, serological reactivity, modes of transmission and molecular characteristics using real- 


\section{Elsayed E. Wagih et al., 2021}

time reverse transcription-polymerase chain reaction (qRT-PCR).

\section{MATERIALS AND METHODS}

\subsection{Virus source}

Samples suspected of being infected with CMV were collected separately in plastic bags from naturally infected plants, pepper, tomato, cucumber, wild tobacco, eggplant grown at different locations, from four governorates in Egypt (Borg El-Arab and El-Bangar, Alexandria; Sakha, Desok and Fowa, Kafr El-Sheik; Rosetta, El-Beheira; Gamasa, Dakahliya). Nicotiana glutinosa seedlings were used for biological detection of CMV in collected samples. Positively reacting samples on $N$. glutinosa were divided into two portions. The first portion of each sample was kept frozen in the deep freezer for subsequent studies, while the other portion was later used to confirm the identity of CMV by indirect ELISA, reaction of diagnostic hosts and qRT-PCR.

\subsection{Serological detection by indirect ELISA}

Naturally infected samples that reacted positively with $N$. glutinosa and suspected of being infected with CMV were used for serological detection by indirect ELISA using specific polyclonal antiserum to CMV. Indirect ELISA first reported by Koenig (1981) with some modifications, applied by Abd El-Monsif (2016), was used for virus detection. ELISA values measured by Universal automated microplate reader ELx 800 and readings were expressed as absorbance at $405 \mathrm{~nm}$. Readings representing tested samples were considered significant if their corresponding absorbance exceeded twice that of the healthy control.

\subsection{Reaction of diagnostic hosts}

Eleven plant species, belonging to five different families, namely Amaranthaceae, Apocynaceae, Cucurbitaceae, Fabaceae and Solanaceae were inoculated with the test CMV isolates from cucumber (from Desok, Kafr El-Sheik) and wild tobacco (from Borg El-Arab, Alexandria). Tissues harboring suspected viruses were inoculated on diagnostic hosts including Catharanthus roseus, Chenopodium amaranticolor and C. quinoa, Cucumis sativus, Cucurbita pepo, Vigna unguiculata, Solanum lycopersicum, Nicotiana glutinosa, N. tabacum cv. White Burley, N. tabacum cv. Xanthi-nc and Datura metel. These diagnostic hosts are known to give characteristic symptoms for CMV (Francki et al., 1979; Palukaitis and García-Arenal, 2003; Zitter and
Murphy, 2009). Plants to be inoculated were used at the age of 2-4 leaf stage except these of Cucurbitaceae which were inoculated at the cotyledon stage. The inoculation technique was carried out as described elsewhere (Kim et al., 2014)

\subsection{Detection by real-time reverse transcription- polymerase chain reaction ( $q R T-P C R)$}

\subsubsection{RNA extraction}

Total RNA was extracted from $100 \mathrm{mg}$ (fresh weight) of either diseased or healthy leaves of $N$. glutinosa using GeneJet RNA Purification $\mathrm{Kit}^{\mathrm{TM}}$ (Thermo scientific, Company). The pellet of RNAs were eluted in $50 \mu \mathrm{l}$ of nuclease free water followed by centrifugation at $12,000 \mathrm{xg}$ for $1 \mathrm{~min}$. The flow through was discarded and the supernatant was kept at $-20^{\circ} \mathrm{C}$ for further studies.

\subsubsection{Primer design:}

The sequence of the oligonucleotides constituting the forward and the reverse CMV specific primers of CP region as follows: A forward primer $-5^{\prime}$ TATGATAAGAAGCTTGTTTCGCGCA$3^{\prime}$ and a reverse primer $-5^{\prime}$ TTTTAGCCGTAAGCTGGATGGACAACCC-3'.

Their sequences could generate an amplification fragment with expected length of $500 \mathrm{bp}$. (Dietzgen et al., 2001).

\subsubsection{Real-time reverse transcription polymerase chain reaction (qRT-PCR)}

The cDNA synthesis reaction was carried out in a total volume of $20 \mu \mathrm{l}$ containing: $4 \mu \mathrm{l}$ of RNA template (about $50 \mathrm{ng}$ ), $0.4 \mu \mathrm{l}$ RiboSafe RNase Inhibitor, $1 \mu 1$ of each primer, $0.2 \mu l$ of reverse transcriptase, the volume completed with $13.4 \mu \mathrm{l}$ DEPC- $\mathrm{H}_{2} \mathrm{O}$ RNase free. The RT mixture was set up on ice, then vortexed for few seconds. The reaction conditions were: one cycle of $45^{\circ} \mathrm{C}$ for $10 \mathrm{~min}$ as reverse transcription, one cycle of $95^{\circ} \mathrm{C}$ for $2 \mathrm{~min}$ as polymerase activation, 40 cycles of $95^{\circ} \mathrm{C}$ for $5 \mathrm{sec}$ (denaturation), $60^{\circ} \mathrm{C}$ for $10 \mathrm{sec}$ (annealing) and a final extension cycle at $72^{\circ} \mathrm{C}$ for $5 \mathrm{sec}$.

\subsubsection{Polymerase chain reaction}

The amplification product (amplicon) was reamplified by the conventional PCR using Master Mix (Taq DNA Polymerase, DNA Polymerase buffer and dNTPs), with the same primers. PCR reaction was carried out using a thermal cycler (Primus 25 Advanced $^{\circledR}$, Peqlab Company) in $25 \mu \mathrm{L}$ mixture containing: $12.5 \mu \mathrm{l}$ of Master Mix (MyTaq ${ }^{\mathrm{TM}} \mathrm{Red}$ 


\section{Scientific Journal of Agricultural Sciences 3 (1): 144-157, 2021}

Mix), $0.5 \mu 1$ of each primer, $3 \mu 1$ of cDNA (template), $8.5 \mu 1$ of sterile nuclease-free distilled water. The PCR reaction conditions were as follows: one cycle of $90^{\circ} \mathrm{C}$ for $45 \mathrm{sec}$ as initial denaturation, 40 cycles of $94^{\circ} \mathrm{C}$ for $45 \mathrm{sec}$ (denaturation), $60^{\circ} \mathrm{C}$ for $45 \mathrm{sec}$ (annealing) and $72^{\circ} \mathrm{C}$ for 1 min (extension) and a final extension cycle at $71^{\circ} \mathrm{C}$ for $10 \mathrm{~min}$. The PCR products were loaded into $1.5 \%$ agarose gel. DNA bands were visualised on a UV-transilluminator.

\subsection{Inoculation, biological purification and maintenance}

CMV isolated from cucumber and wild tobacco was maintained on $N$. glutinosa which served as a source of the virus for subsequent studies. Isolates of CMV selected for study were biologic ally purified by selecting out a local lesion from these elicited on Chenopodium amaranticolor.

\subsection{Mechanical inoculation}

Except otherwise stated, virus inoculation of each isolate was separately prepared by grinding infected leaf sample $(1: 10, \mathrm{w} / \mathrm{v})$ in $0.01 \mathrm{M}$ sodium phosphate buffer ( $\mathrm{pH}$ 7.0) containing $0.5 \% \quad 2$ mercaptoethanol using sterilised and pre-chillded mortar and pestle. Leaves of healthy plants to be inoculated were first dusted with carborundum (600 mesh) then mechanically inoculated by rubbing with forefinger previously dipped into infected-sap of finely ground leaves of each virus isolate. Healthy or inoculated plants were maintained at $25-28{ }^{\circ} \mathrm{C}$ under glasshouse conditions and observed daily for four weeks after inoculation for symptom development. Inoculated plants that showed no symptoms were checked for latent or masked infection by backinoculation to Chenopodium amaranticolor.

\subsection{Propagation of CMV isolates}

Seeds of N. glutinosa and Cucurbita pepo were sown in $25 \mathrm{~cm}$ diameter pots filled with autoclaved sandy loam soil. For each CMV isolate, six replicates were used for mechanical inoculation at 2-3 leaf stage except the Cucurbitaceae members which were inoculated at the cotyledonary stage of plant development. Six replicates, three seedlings each, were left without inoculation and served as a control. Healthy and CMV-inoculated plants were kept under glasshouse conditions.

\subsection{Mode of transmission}

\subsubsection{Mechanical transmission}

Leaves of healthy plants to be inoculated for studying mechanical transmissibility of the virus were first dusted with carborundum (600mesh) then mechanically inoculated by rubbing with forefinger previously dipped into infected-sap of finely ground leaves of each virus isolate as outlined under mechanical inoculation subtitle.

\subsubsection{Aphid transmission}

Four aphid species were tested for the ability to transmit the two isolates of CMV investigated in this study from infected to healthy cucumber plants. Aphid species were collected separately from the fields as Aphis gossypii (Glover), Aphis nerii (Boyer), Myzus persicae (Sulzer) and Rhopalosiphum maidis (fitch). For starvation, each group of aphid species were held for an hour in a Petri plate then transferred to the CMV-infected plants. After a period of 5-10 min acquisition feeding, aphids were placed on 10 healthy caged cucumber plants (first true leaves), at a ratio of 10 aphids/plant, and kept overnight. The same procedure was used for control treatment, except virus-free aphids were used. After 24h, treated seedlings were sprayed with Malathion (0.1\%). Inoculated plants were kept under insect proof cages, and continually observed for 2 weeks for symptom development.

\subsubsection{Seed transmission}

An experiment was conducted to study seed transmissibility of CMV. Fifty seeds of squash cv. Eskandrani for each isolate of CMV and fifty seeds as control were soaked in tap-water for 48 hours then sowed in $50 \mathrm{~cm}$ pots containing a sterilised soilpeatmoss-sand mixture and kept under glasshouse conditions. After emergence of cotyledonary leaves, seedlings were mechanically inoculated with CMVwild tobacco and CMV-cucumber isolates, and phosphate buffer-inoculated plants served as control. Fifty replicates were used for each isolate treatment and each replicate consisted of one plant. Plants were weekly fertilised by N-P-K (SUPER FEED, 19-1919) $1 \mathrm{~g} /$ litre. Seedlings were checked for potential symptom development after seed germination and left to produce seeds. For each treatment, total number of seeds, number of empty seeds, number of fullness seeds were calculated. Collected seeds were sown in seedling trays (one germinated seed per well) containing sterilised soil (peatmoss-sand mixture) and kept under glasshouse condition. Emerged seedlings 
were counted and kept under observation for symptom development over three weeks. Random samples from seedlings generated from seeds of infected and healthy plants were collected and tested by indirect ELISA for virus detection. Percentage of germination and virus seed transmission were calculated.

\section{RESULTS}

\subsection{Symptomology and virus detection of naturally infected plants}

The naturally infected plants exhibited symptoms including severe mosaic, mild mosaic, chlorosis, mottling, vein banding, blisters, malformation, fern leaf, shoe-string and stunting, suspected of being Cucumber mosaic virus (CMV) symptoms. These symptoms were visually observed on naturally infected cucumber, tomato, pepper and wild tobacco plants at different locations within a number of governorates (Borg El-Arab and El-Bangar
(Alexandria), Sakha, Desok, Fowa (Kafr El-Sheik), Rosetta, (El-Beheira) and Gamasa (Dakahliya). The causal virus of the naturally observed symptoms suspected of being caused by CMV was identified based on symptomology, reaction of diagnostic hosts, serology using indirect ELISA with CMV-specific antiserum and eventually real time-reverse transcription polymerase chain reaction (qRT-PCR).

\subsection{Serological detection using indirect ELISA}

Serological detection by indirect ELISA (Table 1) revealed that the virus associating the previously described symptoms of naturally infected plants was CMV in only two samples (wild tobacco from Borg El-Arab and cucumber from Desok) out of the eight samples tested (Fig. 1) as they gave a strong positive reaction with a CMV-specific antiserum, whereas the other samples showed no reaction with the same antiserum.

Table 1. Serological reaction of samples taken from different naturally infected plants collected from different locations in a number of governorates using indirect ELISA technique and CMV specific antiserum.

\begin{tabular}{|c|c|c|c|c|}
\hline \multirow{2}{*}{ Test sample } & \multirow{2}{*}{ Location } & \multirow{2}{*}{ Governorate } & \multicolumn{2}{|c|}{$\begin{array}{l}\text { Indirect ELISA reading* } \\
(\text { (E 405nm) }\end{array}$} \\
\hline & & & Healthy & Sample \\
\hline Cucumber & Desok & Kafr El-Sheik & 0.121 & 0.249 \\
\hline Cucumber & Gamasa & Dakahliya & 0.111 & 0.127 \\
\hline Eggplant & El-Bangar & Alexandria & 0.033 & 0.030 \\
\hline Pepper 1 & Fowa & Kafr El-Sheik & 0.038 & 0.037 \\
\hline Pepper 2 & Sakha & Kafr El-Sheik & 0.046 & 0.044 \\
\hline Tomato & Rosetta & El-Beheira & 0.126 & 0.184 \\
\hline Wild tobacco 1 & Borg EL-Arab & Alexandria & 0.124 & 0.090 \\
\hline Wild tobacco 2 & Borg EL-Arab & Alexandria & 0.126 & 0.258 \\
\hline
\end{tabular}

*, ELISA readings in terms of extinction at $405 \mathrm{~nm}(\mathrm{E} 405 \mathrm{~nm})$ are the mean value of two replicates each. Extinction values of at least double that of the healthy control were considered positive; Bold = Positive reaction 


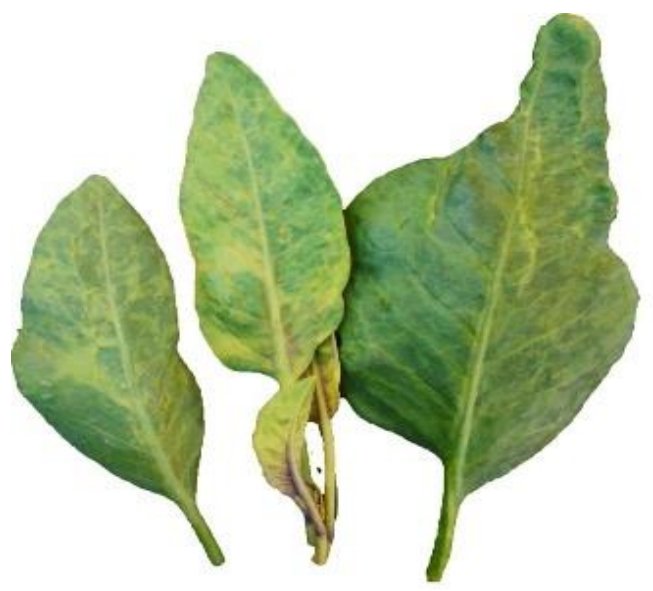

A
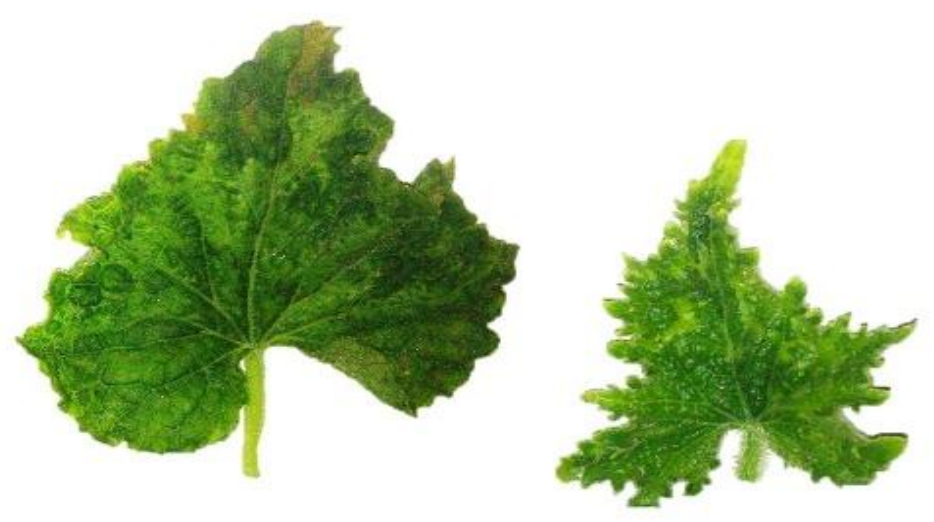

B

Fig. 1. A, naturally infected wild tobacco (Nicotiana glauca) plant leaves showing mosaic and malformation symptoms from Borg El-Arab (Alexandria), B, naturally infected cucumber (Cucumis sativus) plant leaves showing mosaic, green vein banding, blisters and malformation symptoms on plants growing in Desok (Kafr El-Sheik) and suspected of being naturally infected with CMV.

\subsection{Reaction of diagnostic hosts}

The two isolates of CMV, namely, CMV-wild tobacco and CMV-cucumber, investigated here were found to be infectious to cucumber and many other hosts. CMV-wild tobacco isolate developed severe symptoms on test plants, while CMV-cucumber isolate induced mild symptoms. Reactions of diagnostic hosts to the two isolates are presented in Table 2.

Table 2. Differential reaction of some diagnostic hosts to inoculation with two isolates of Cucumber mosaic virus (CMV), namely CMV-wild tobacco and CMV-cucumber.

\section{Diagnostic host}

Isolate*/Host reaction**

$$
\text { CMV-wild tobacco }
$$

NLL

PPNLL

LP/CLL

$$
\begin{gathered}
\mathrm{M} / \mathrm{Chl} \\
\mathrm{M} / \mathrm{Ch} \mathrm{H} / \mathrm{GVB} / \mathrm{B}
\end{gathered}
$$

NLL

LP/VY

$\mathrm{SM} / \mathrm{GVB} / \mathrm{LD}$

$\mathrm{SM}$

$\mathrm{SM} / \mathrm{B} / \mathrm{Chl} / \mathrm{Mf}$

$\mathrm{M} / \mathrm{GVB}$
CMV-cucumber

NLL

NLL

$\mathrm{Chl} / \mathrm{M}$

$\mathrm{M} / \mathrm{VC} / \mathrm{GVB}$
$\mathrm{MM} / \mathrm{Y} / \mathrm{B}$

NLL

VY
M/Chl/B/LD
MM
$\mathrm{M}$
$\mathrm{MM}$

Solanum Lycopersicum

*, CMV-wild tobacco, Cucumber mosaic virus isolated from Alexandria; CMV-cucumber, from Desok.

$* *, \mathrm{~B}=$ Blister, $\mathrm{Chl}=$ Chlorosis, $\mathrm{CLL}=$ Cholorotic local lesions, $\mathrm{LD}=$ leaf deformation, $\mathrm{LP}=\mathrm{Line}$ pattern, $\mathrm{M}=$ Mosaic, $\mathrm{Mf}=$ malformation, $\mathrm{MM}=$ Mild mosaic, $\mathrm{NLL}=$ Necrotic local lesions, $\mathrm{PPNLL}=$ Pinpoint necrotic local lesion, $\mathrm{SM}=$ Severe mosaic, $\mathrm{VC}=$ Vein clearing, $\mathrm{GVB}=$ Green vein banding, $\mathrm{VY}=$ Vein yellowing, $\mathrm{Y}=$ Yellowing. 
These isolates caused mild to severe mosaic and blisters on plants of Nicotiana glutinosa, $N$. tabacum cv. Xanthi-nc and N. tabacum cv. White Burley, respectively (Fig. 2). Tested isolates produced vein banding followed by systemic chlorotic mottling, raised green blisters and stunting on Cucurbita pepo (Fig. 3) and vein banding, mild mosaic and severe mosaic with blisters on Cucumis sativus. In Solanum lycopersicum, CMV-wild tobacco isolate produced mosaic and green vein banding whereas CMV- cucumber isolate showed mild mosaic symptoms. Reaction of mechanical inoculation of localised symptoms (pin-point necrotic local lesions and necrotic local lesions) was observed on Vigna unguiculate, Chenopodium amaranticolor and $C$. quinoa (Fig. 4), respectively. Line pattern, chlorosis and chlorotic local lesions symptoms were observed on Catharanthus roseus (Fig. 5) and Datura metel, respectively.
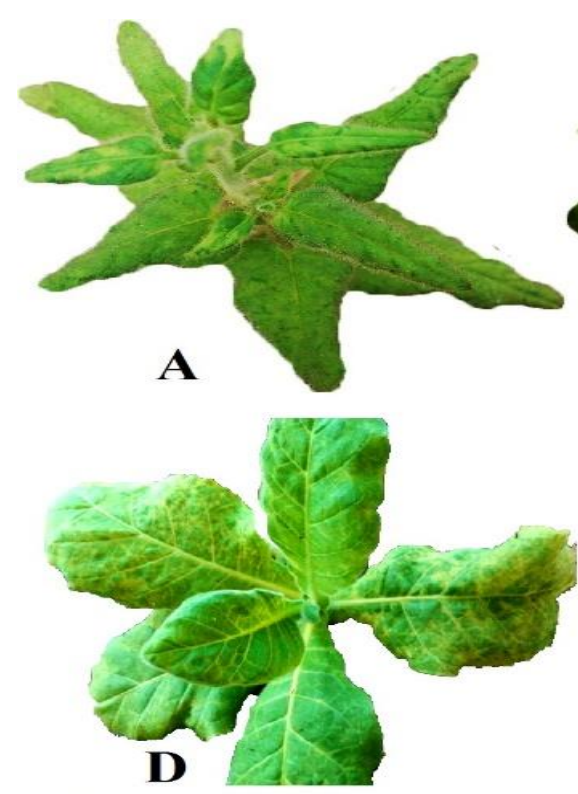

B

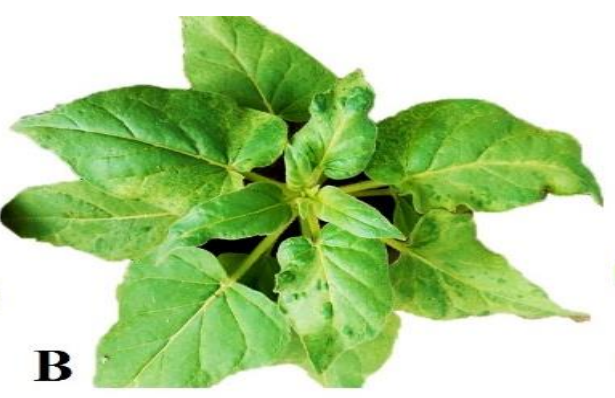

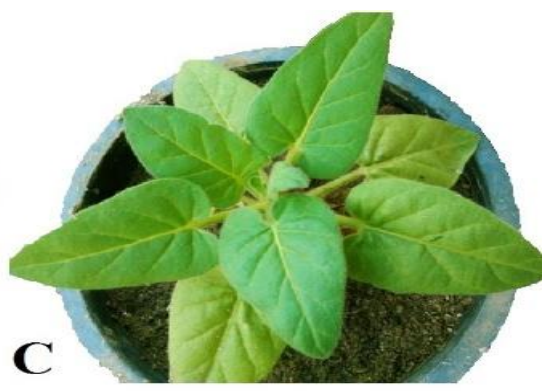
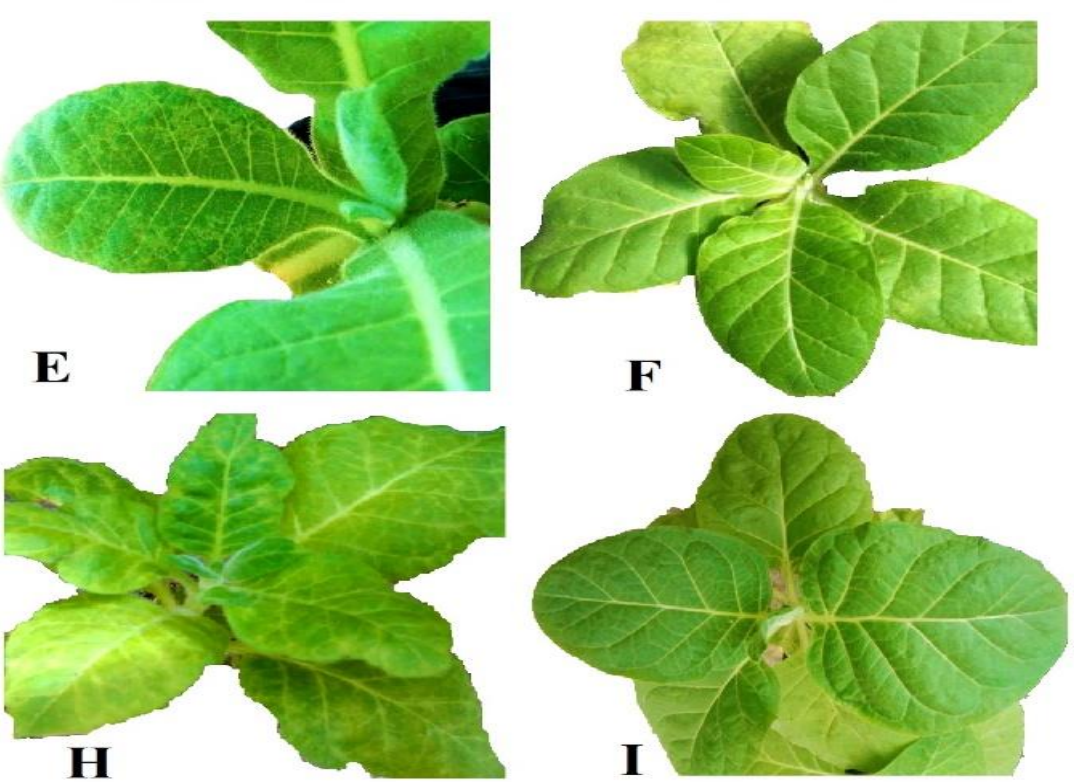

$\mathbf{H}$

I

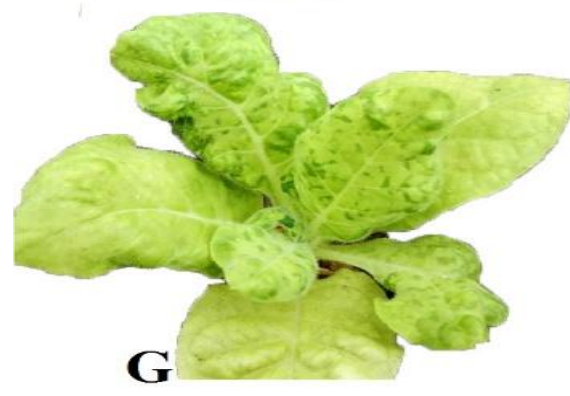

Fig. 2. Tobacco (Nicotiana glutinosa) plants showing severe mosaic, green vein banding and leaf deformation induced by the CMV-wild tobacco isolate (A) and mosaic, blistering and malformation elicited by a CMV-cucumber isolate (B), 25 days post-inoculation as compared to phosphate buffer mockinoculated healthy plant $(C)$. Tobacco $(N$. tabacum cv. Xanthi-nc) plants expressing severe mosaic symptoms with CMV-wild tobacco isolate (D) and mild mosaic symptoms induced by CMV-cucumber isolate $(E), 25$ days post-inoculation as compared to phosphate buffer mock-inoculated healthy plants $(F)$ where no symptoms were observed. Severe mosaic, blistering and malformation on $N$. tabacum cv. White Burley plants, 25 days post-inoculation with CMV-wild tobacco isolate (G) and mild mosaic and mottling with CMV-cucumber (H), as compared to phosphate buffer mock-inoculated healthy plants (I). 

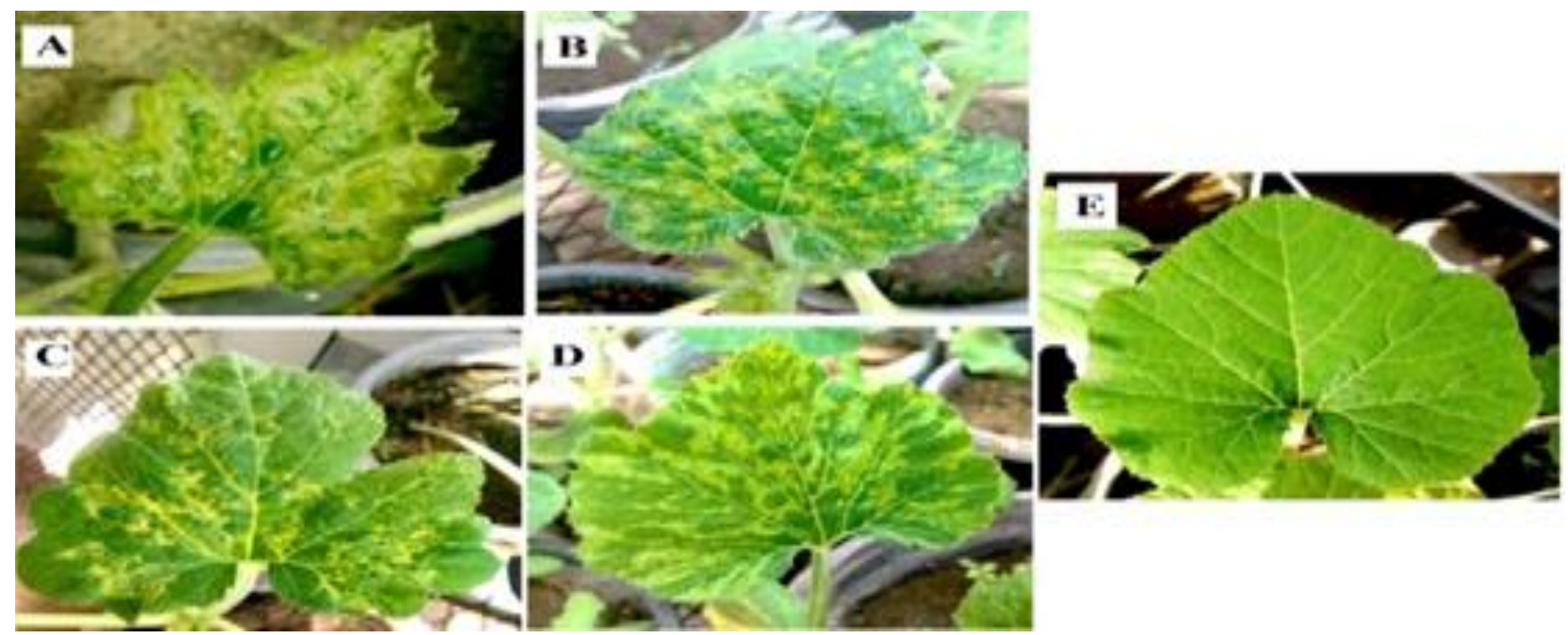

Fig. 3. Squash (Cucurbita pepo) plant leaf showing mosaic, blistering (A) and chlorotic intercoastal areas (B) induced by $\mathrm{CMV}$-wild tobacco isolate, leaf expressing mosaic and vein yellowing $(\mathrm{C})$ green vein banding and yellowing of intercoastal areas (D) induced by CMV-cucumber isolate, 25 days postinoculation as compared to phosphate buffer mock -inoculated healthy plant leaf (E).
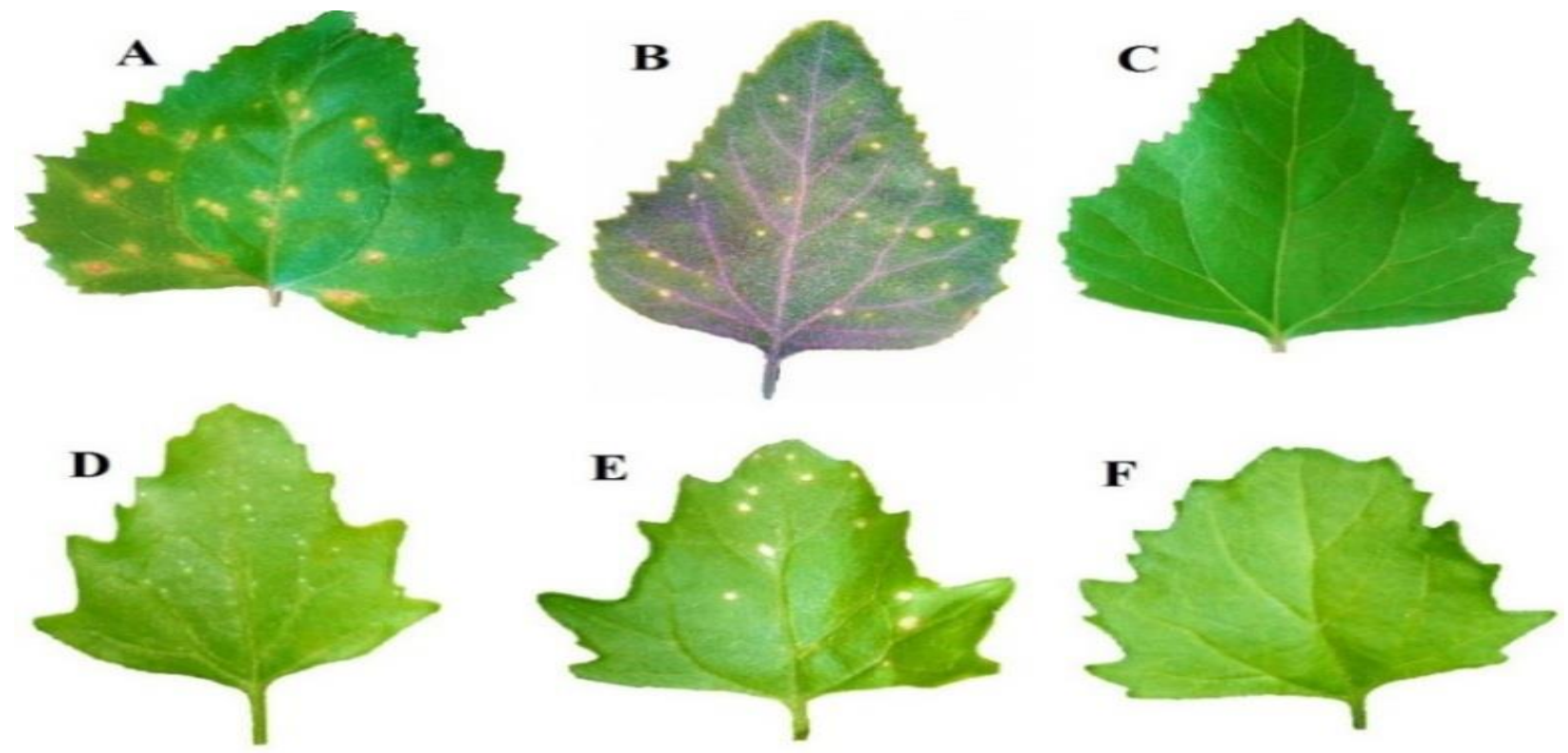

Fig. 4. A goosefoot (Chenopodium amaranticolor) plant leaves showing necrotic local lesions surrounded by reddish halo induced by the CMV-wild tobacco isolate (A) and necrotic local lesions elicited by the CMV-cucumber isolate (B), 5 days post-inoculation as compared to phosphate buffer mock-inoculated healthy leaf $(C)$. A quinoa $(C$. quinoa) plant leaf showing pin-point necrotic local lesions induced by a CMV- wild tobacco isolate (D) and necrotic local lesions elicited by CMV-cucumber isolate (E), 5 days post-inoculation as compared to phosphate buffer mock -inoculated healthy leaf (F). 

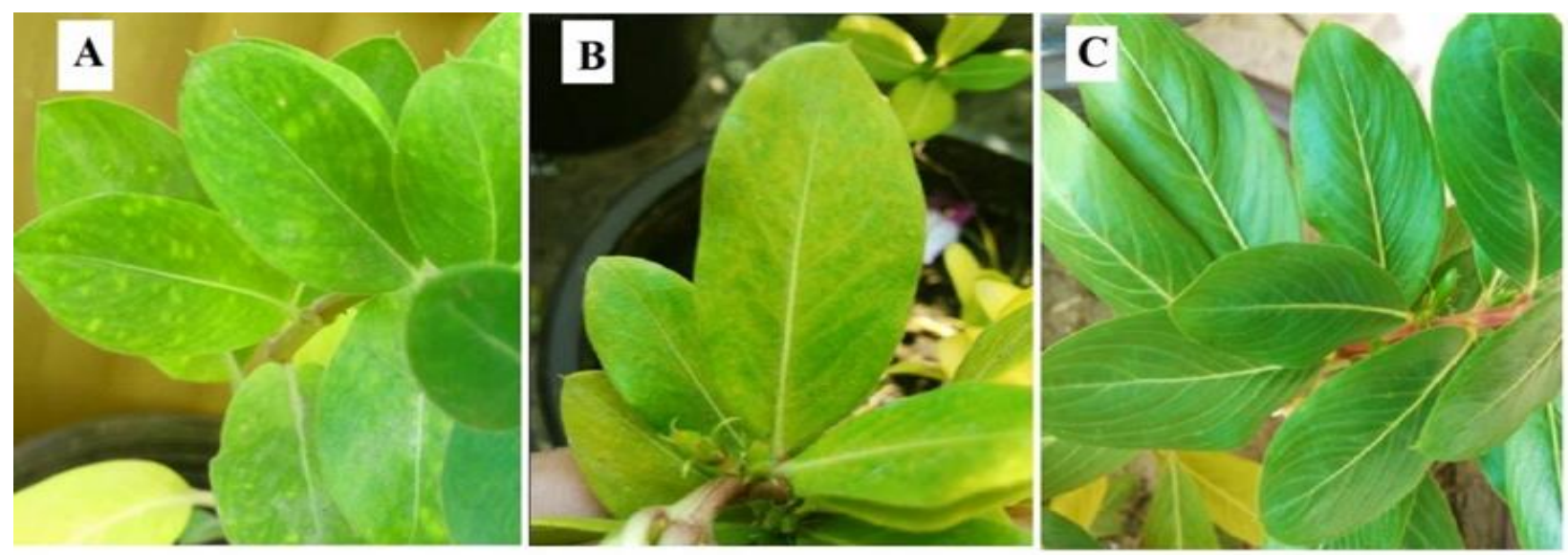

Fig. 5. Catharanthus roseus leaves expressing chlorotic local lesions and line pattern induced by a CMVwild tobacco isolate (A) and mosaic symptoms when inoculated with the CMV -cucumber isolate (B), 20 days post-inoculation as compared to phosphate buffer mock-inoculated healthy leaves (C).

3.4. Detection of CMV by real time-polymerase chain reaction (qRT-PCR)

qRT-PCR was performed on total RNA extracted from $N$. glutinosa leaf samples separately infected with CMV-wild tobacco and CMV-cucumber isolates using a pair of sequence-specific primers of the coat protein gene. The molecular length of the amplified product was approximately $500 \mathrm{bp}$ for CMV-wild tobacco and CMV-cucumber (Fig. 6).

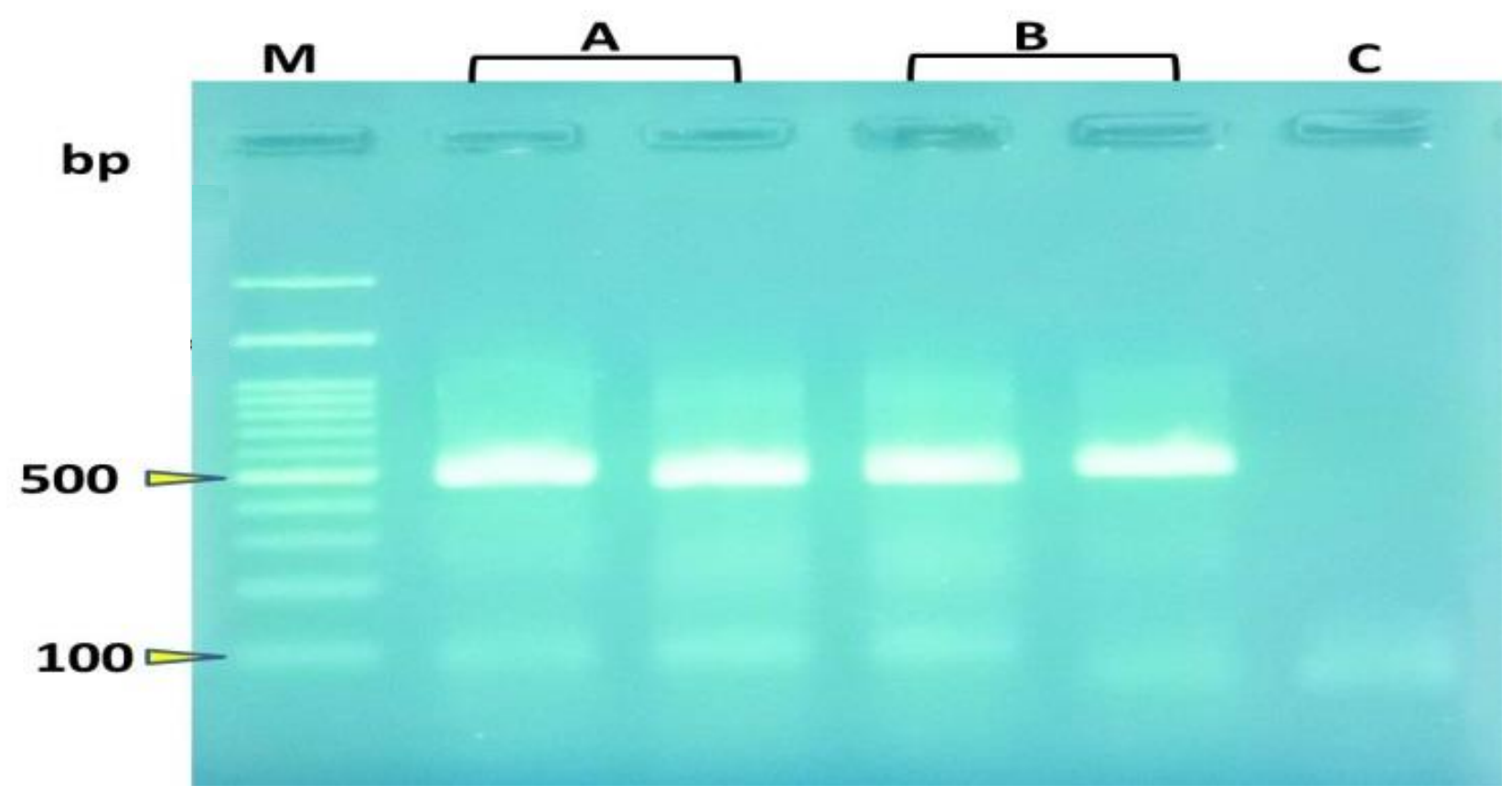

Fig. 6. Agarose $(1.5 \%)$ gel electrophoresis showing re-amplification product of PCR with a molecular length of $500 \mathrm{bp}$, when the traditional PCR analysis with a pair of coat protein sequence-specific primers was conducted on the cDNA produced from $q R T-P C R$. A, two replicate lanes corresponding to CMVwild tobacco isolate; $B$, two replicate lanes representing the $\mathrm{CMV}$-cucumber isolate. $\mathrm{C}$, healthy control leaves. Gel was stained with RedSafe dye and bands visualised under ultraviolet radiations. Left Lane (M) is a $3 \mathrm{kbp}$ DNA marker ladder. 


\subsection{Biological studies}

\subsubsection{Modes of transmission}

The two CMV isolates (CMV-wild tobacco and $\mathrm{CMV}$-cucumber) included in this investigation were studied for their transmissibility by different methods (mechanical, aphid and seed).

\subsubsection{Mechanical transmission}

Results of mechanical transmission revealed that both CMV isolates (CMV-wild tobacco and CMVcucumber) are easily mechanically transmissible from inoculum source (Nicotiana glutinosa) to different assay hosts where typical symptoms were observed.

\subsubsection{Aphid transmission}

Four aphid species were tested for their ability to transmit the two isolates of CMV from infected to healthy cucumber plants. Results presented in Table 3 revealed that CMV-wild tobacco and CMV-cucumber isolates were transmitted, non-persistently, by the four aphid species, albeit with different efficiencies. Myzus persicae (Sulzer) and Aphis gossypii (Glover) transmitted the two virus isolates at the highest rate for both CMV-wild tobacco and CMV-cucumber isolates with a transmission percentage of $90-80 \%$ and 70-80\%, respectively, whereas Rhopalosiphum maidis (Fitch) and Aphis nerii (Boyer) transmitted them at lower rates, with a percentage of $60-40 \%$ and 50-30\%, respectively.

Table 3. Transmission of CMV-wild tobacco and CMV-cucumber isolates from infected to healthy plants by four Aphid species.

\begin{tabular}{ccccc}
\hline & \multicolumn{2}{c}{ CMV-wild tobacco } & \multicolumn{2}{c}{ CMV-cucumber } \\
\cline { 2 - 5 } Aphid species* & $\begin{array}{c}\text { No. infected } \\
\text { plants/no. tested } \\
\text { plants }\end{array}$ & $\begin{array}{c}\text { Transmission } \\
(\boldsymbol{\%}) * *\end{array}$ & $\begin{array}{c}\text { No. infected } \\
\text { plants/no. tested } \\
\text { plants }\end{array}$ & $\begin{array}{c}\text { Transmission } \\
(\%) * *\end{array}$ \\
\hline $\begin{array}{c}\text { Aphis gossypii } \\
\text { (Glover) }\end{array}$ & $7 / 10$ & 70 & $8 / 10$ & 80 \\
Aphis nerii (Boyer) & $5 / 10$ & 50 & $3 / 10$ & 30 \\
$\begin{array}{c}\text { Myzus persicae } \\
\text { (Sulzer) }\end{array}$ & $9 / 10$ & 90 & $8 / 10$ & 80 \\
$\begin{array}{c}\text { Rhopalosiphum } \\
\text { maidis (Fitch) }\end{array}$ & $6 / 10$ & 60 & $4 / 10$ & 40 \\
\hline
\end{tabular}

*, 10 aphids per plant.

**, Percentage of transmission was calculated by dividing number (No.) of infected plants by No. of tested plants multiplied by 100 .

\subsubsection{Seed transmission}

Results showed that symptoms were clearly observed on artificially inoculated plants 7 days postinoculation. After maturation, seeds were collected from the infected plants then replanted, the progeny seedlings were free of CMV symptoms and no virus was detected either from inoculated or apparently healthy plants. Indirect ELISA showed that neither
CMV-wild tobacco isolate nor CMV-cucumber isolate could be transmitted through Cucurbita pepo (squash) seeds. It was also evident that seed yield and seed germination of inoculated plants with CMV isolates were reduced by infection (Table 4). Total number of mature seeds collected from plants infected with CMV-wild tobacco and CMV-cucumber as well as healthy plants was 342, 290 and 582, respectively. 
Elsayed E. Wagih et al., 2021

Table 4. Effect of infection with the two CMV isolates (CMV-wild tobacco and CMV-cucumber) on seed yield and germination percentage.

\begin{tabular}{lcccc}
\hline \multirow{2}{*}{ Treatment } & \multicolumn{3}{c}{ Number of seeds/Treatment } & Germinated seeds \\
\cline { 2 - 4 } & $\begin{array}{c}\text { Total number } \\
\text { of seeds }\end{array}$ & Empty & Fullness of seeds & \\
\cline { 2 - 3 } & 342 & 76 & 266 & $169(49)$ \\
CMV-wild tobacco & 290 & 51 & 239 & $181(62)$ \\
CMV-cucumber & 582 & 32 & 550 & $400(68)$ \\
Control & $582)$ &
\end{tabular}

*, Percentage (\%) of germinated seeds was calculated by dividing the number (No.) of germinated seeds by the total number of seeds multiplied by 100 .

\section{DISCUSSION}

Cucumber mosaic virus (CMV) is one of the most important plant viruses causing losses in several crops (Zitter and Murphy, 2009). Various kinds of symptoms are produced by CMV on different hosts. The naturally infected plants that were growing in different locations in Egypt and from which the specimens used as a source of the two isolates (CMVwild tobacco and CMV-cucumber) were collected, showed symptoms closely similar to those caused by CMV. The positive reaction of the two isolates suspected of being of CMV and used throughout this study with a CMV-specific polyclonal antiserum when tested with indirect ELISA confirms that the obtained isolates are of CMV.

The CMV-characteristic necrotic local lesion reaction of cowpea (Vigna unguiculata L.) primary leaves as a diagnostic host following inoculation with the two isolates indicated that the two isolates belonged to CMV. These results were in agreement with those of Kim et al. (2014), but contrasted with those of Palukaitis and Garcia-Arenal (2003).

The necrotic local lesions induced, without systemic spread, by the two isolates on Chenopodium amaranticolor, Chenopodium quinoa and Vigna unguiculata and the systemic symptoms obtained on N. glutinosa, N. tabacum cv. Xanthi-nc, N. tabacum cv. White Burley, Solanum lycopersicum, Cucumis staivus, Catharanthus roseus and Datura stramonium are known to be inducible by CMV. These results were in agreement with those of Gibbs and Harrison (1970) and Rasoulpour and Izadpanah (2008). The fact that the CMV-wild tobacco isolate elicits necrotic local lesions surrounded with reddish halos on Chenopodium amaranticolor as reported before by Younes (1995) and Abd El-Aziz (2015), while CMVcucumber isolate induces necrotic local lesions without reddish halos as described by Kim et al. (2014) could be used as a differential host reaction to discriminate between the two isolates. Additionally, the pinpoint necrotic local lesions elicited by CMVwild tobacco on Chenopodium quinoa which were similar to those reported by Kim et al. (2011 and 2014) and the necrotic local lesions caused by CMVcucumber isolate like those observed before (Younes, 1995; Palukaitis and Garcia-Arenal, 2003 and Rasoulpour and Izadpanah, 2008) add further evidence that the two isolates belong to CMV.

The finding that CMV-wild tobacco isolate produced vein banding, severe mosaic and leaf deformation on $N$. glutinosa and that CMV-cucumber isolate induced mosaic, chlorosis, blisters and leaf malformation on infected plants was in agreement with those observed before for CMV (Francki et al., 1979; Younes, 1995; Palukaitis and Garcia-Arenal, 2003). Nicotiana tabacum cv. Xanthi-nc, which displayed severe mosaic on plants infected with the CMV-wild tobacco isolate, but reacted with mild mosaic when inoculated with the CMV-cucumber isolate, confirmed the pathological difference between the two isolates. N. tabacum cv. White Burley reacted with severe mosaic, blistering, chlorosis and malformation to the CMV-wild tobacco isolate, but mild mosaic and mottling with the CMV-cucumber isolate. Regardless of severity, these symptoms corresponded to those described by Rao and Francki (1982), Zitikaite and Urbanaviciene (2010) and Megahed et al. (2012) for CMV.

Cucurbita pepo reacted differently to both CMV isolates. CMV-wild tobacco produced systemic mosaic and chlorosis followed by yellowing and blistering while CMV-cucumber induced vein clearing and vein banding followed by interveinal chlorosis and leaf deformation. Again, regardless of severity, these symptoms were similar to those characteristics to CMV as reported by Younes (1995), Megahed et al. (2012) and Kim et al. (2014). Cucumis sativus showed mosaic, green vein banding and chlorosis when infected with the CMV-wild tobacco isolate and mild mosaic, yellowing and blistering with the CMV-cucumber isolate. Although these results were not much helpful in differentiating the two isolates, they resembled those obtained for CMV by other investigators (Zitikaite and Urbanaviciene, 


\section{Scientific Journal of Agricultural Sciences 3 (1): 144-157, 2021}

2010; Megahed et al., 2012; Pratap et al., 2012; Eldougdoug et al., 2013).

On tomato (Solanum lycopersicum L.) cv. Super strain B, mosaic and green vein banding symptoms were induced by the CMV-wild tobacco isolate matching those reported by Sulistyowati et al. (2004) and El-dougdoug et al. (2013), whereas only mild mosaic was observed on plants inoculated with the CMV-cucumber isolate, a symptom similar to that reported by Pratap et al. (2012).

Although the CMV-cucumber isolate caused mosaic on Catharanthus roseus, the CMV-wild tobacco isolate produced line pattern and chlorotic local lesions that were dissimilar to those described by Mahmoud (2011) and Abd El-Aziz (2015).

The symptoms appearing on Datura metel in the form of line pattern and vein yellowing when infected with the CMV-wild tobacco isolate and vein yellowing when the CMV-cucumber isolate with the virus involved differed from those obtained by Rasoulpour and Izadpanah (2008) and El-dougdoug et al. (2013).

The variability observed in the foregoing part of the discussion between the two isolates, CMV-wild tobacco and CMV-cucumber and between them and those reported in the literature could be attributed to several factors including plant cultivars, geographical location, virus reservoir, alternative hosts, virus strain and environmental conditions.

The CP gene of CMV isolates was successfully amplified using real time reverse transcription-polymerase chain reaction (qRT-PCR) using a total RNA preparation from the CMV propagative host $N$. glutinosa as template and the generation of a single RT-PCR amplification product of $500 \mathrm{bp}$ long when RT-PCR technique was applied with a pair of specific primers to the CMV isolates investigated here validates the identity of the virus. This finding is supported by a similar result previously obtained by Dietzgen et al. (2001) and Shevchenko et al. (2015).

The ease by which the two CMV isolates, CMV-wild tobacco and CMV-cucumber, investigated here can be mechanically transmitted is in line with those reported by Hull (2002) and Dheepa and Paranjothi (2010).

Studying the involvement of four aphid species, namely Aphis gossypii (Glover), Aphis nerii (Boyer), Myzus persicae (Sulzer) and Rhopalosiphum maidis (Fitch) in transmitting CMV has thrown extra light on this relationship. The fact that $M$. persicae transmitted the CMV-wild tobacco isolate at a percentage of $90 \%$ while it transmitted the CMV- cucumber at a percentage of $80 \%$ and that with both CMV isolates the percentage of transmission by $A$. gossypii amounted to $70 \%$ and $80 \%$, respectively go along, in trend, with those obtained by other workers (lecoq et al., 1979; Napier, 2009; Abd El-Aziz, 2015). The finding that $A$. nerii is the least efficient vector in transmitting the two CMV isolates with 50\% efficiency in transmitting CMV-wild tobacco isolate and only $30 \%$ in transmitting CMV-cucumber isolate disagree with those of Hobbs et al. (2000) and Abd El-Aziz (2015). The variability observed in the efficiency of aphid species as to transmitting CMV could be due to individual differences among isolates or strains, aphid species and/or environmental conditions.

The inability of CMV isolates, CMV-wild tobacco and CMV-cucumber, used here to be transmissible through seeds of infected Cucurbita pepo plants agree with the results obtained by Saric and Stefanac (1988) who reported that, CMV is not seed transmissible through cucurbits seeds. However, other workers (Sharma and Chohan, 1974; Al-Tamimi et al., 2009; Sevik and Balkaya, 2015) reported contradictory results by showing that the virus is transmitted through seeds, yet at a low percentage.

\section{CONCLUSION}

Two isolates of Cucumber mosaic virus (CMV), CMV-wild tobacco (from Alexandria) and CMV-cucumber (from Kafr El-sheikh) have been recognised as members of the CMV community in Egypt when partially characterised based on the reaction of diagnostic hosts, symptomology, serological reactivity, mode of transmission and molecular characteristics using real-time reverse transcription-polymerase chain reaction (qRT-PCR). Unlike many other members of CMV, the two isolates could not be transmitted through Cucurbita pepo seeds derived from infected plants, albeit they had a great effect on seed germination.

\section{ACKNOWLEDGEMENTS}

All authors would thank Prof. Hosny Younes (Department of Agricultural Botany, Faculty of Agriculture, Saba Basha, University of Alexandria) and Dr. Mahmoud Abd El-Aziz (Research Institute, University of Alexandria) for providing the antiserum of CMV. We also thank Prof. Hedaya Hamza and Dr. Mohamed Tawfek, Entomology Department, Faculty of Agriculture, Alexandria University for identification of aphid species. Authors are appreciative to Dr. Dalia Gamil (Genetic Engineering Institute, City of Scientific Research and 
Technological Application, Borg El-Arab City) for supplying the primers of CMV.

Conflict of interest

The authors emphasise that they have no conflict of interest to declare.

\section{REFERENCES}

Abd El-Aziz MA (2015). Studies on some viruses infecting cowpea plants. Ph.D. Thesis. Faculty of Agriculture (Saba-Basha), Alexandria University. Egypt. 136 p.

Abd El-Monsef KA (2016). Characterization of some isolates of Tomato mosaic virus. M.Sc. Thesis. Faculty of Agriculture, Alexandria University. Egypt.136p.

Abu Foul KS (1989). Studies on some viruses affecting pepper plants in northern Egypt. Ph.D. Thesis. Faculty of agriculture Alexandria University. $184 \mathrm{p}$.

Al-Tamimi N, Kawas H, Mansour A (2009). Seed transmission viruses in squash seeds (Cucurbita pepo) in Southern Syria and Jordan Valley. J.J.A.S., 5: 497506.

Carrere I, Tepfer M, Jacquemond M (1999). Recombinants of cucumber mosaic virus (CMV): determinants of host range and symptomatology. Arch. Virol., 144:365-379.

Chikh Ali M, Omar AM, Maoka T, Natsuaki KT, Natsuaki T (2012). Characterization of potato and tobacco isolates of Cucumber mosaic virus from Syria and the first report on CMV satellite RNA from potato. Phytopathol. Mediterr., 51(1):3-10.

Dheepa R, Paranjothi S (2010). Transmission of Cucumber mosaic virus (CMV) infecting banana by aphid and mechanical methods. Emir. J. Food Agr., 22 (2): 117-129.

Dietzgen RG, Callaghan B, Higgins CM, Birch RG, Chen K, Xu Z (2001). Differentiation of peanut seedborne potyviruses and cucumoviruses by RTPCR. Plant Dis., 85: 989-992.

Duarte LML, Rivas EB, Harakava R, Veauvy MCD, Alexandre MAV (2013). Genealogy of Cucumber mosaic virus isolated from ornamental Species. Am. J. Plant Sci., 4: 1081-1087

Eid SA, Kishtah AA, Abo-Zeid AA (1984). Nicotiana glauca L. a natural host for Cucumber mosaic virus. Agricultural Research Review, 62: 367378.

El-dougdoug KA, Sofy AR, Hameed GA, Dawood RA (2013). Intraspecific diversity of Cucumber mosaic cucumoviridae in Egypt. I. J.V., 10 (2):94102.
El-Kady MAS, Eid SA, Kishtah AA (1979). Isolation, purification and electron microscopy of cucumber mosaic virus from bean (Phaseolus vulgaris L.). $3^{\text {rd }}$ Egypt Phytopathology Congress Proceedings, 92-101.

Fegla GI, El-Mazaty MA (1981). Distribution of certain viruses affecting cucurbits in Egypt and susceptibility of cucurbit cultivars to the most prevalent one. A. J. A. R., 1: 247-258.

Francki RIB, Mossop DW, Hatta T (1979). Cucumber mosaic virus. CMI/ AAB Description of Plant Viruses, no.213.

Garcia-Arenal F, Palukaitis P (2008). Cucumber mosaic virus. in: Desk Encyclopedia of Plant and Fungal Virology. Mahy, B. W. J. and Van Regenmortel, M. H. V. Academic Press, 614-618.

Gibbs AJ, Harrison BD (1970). Cucumber mosaic virus. CMI/AAB. Description of plant viruses. No. $14 \mathrm{p}$.

Hobbs HA, Eastburn DM, D'Arcy CJ (2000). Solanaceous Weeds as Possible Sources of Cucumber mosaic virus in Southern Illinois for aphid transmission to pepper. APS, 84 (11): 1221-1224.

Hull $R$ (2002). Matthew's plant virology, $4^{\text {th }}$ ed. Elsevier Academic Press, London, UK.

ICTV (2014). International Committee on Taxonomy of viruses.

Kim JH, Choi GS, Choi JK (2002). Characterization of Cucumber mosaic virus subgroup II isolated from paprika (Capsicum annum var. grossum) in Korea. Plant Pathol. J., 18(1): 6-11.

Kim MK, Kwak HR, Lee SH, Kim JS, Kim KH, Cha BJ, Choi HS (2011). Characteristics of Cucumber mosaic virus isolated from Zea mays in Korea. Plant Pathol. J., 27(4): 372-377.

Kim MK, Jeong RD, Kwak HR, Lee SH, Kim JS, Kim KH, Cha B, Choi1 HS (2014). First report of Cucumber mosaic virus isolated from wild Vigna angularis var. nipponensis in Korea. Plant Pathol. J., 30(2):200-207.

Koenig $R$ (1981). Indirect ELISA methods for the broad specificity detection of plant viruses. J. Gen. Virol., 55:53-62.

Lecoq H, Cohen S, Pitrate M, Labonne G (1979). Resistance to Cucumber mosaic virus transmission by aphids in Cucumis melo. APS, 69:1223-1225.

Lu J, Du ZX, Kong, J, Chen LN, Qiu YH, Li GF, Meng XH, Zhu SF (2012). Transcriptome analysis of Nicotiana tabacum infected by Cucumber mosaic virus during systemic symptom development. PLoS ONE, 7(8): e43447.

Mahmoud SYM (2011). Detection of Cucumber mosaic virus in some ornamental plants and 
elimination of nonspecific ELISA reactions. Arch. Phytopathol. Pflanzenschutz., 44 (14):1410-1424.

Mazidah M, Yusoff K, Habibuddin H, Tan HY, Lau HW (2012). Characterization of Cucumber mosaic virus (CMV) causing mosaic symptom on Catharanthus roseus (L.) G. Don in Malaysia. Pertanika Journal of Tropical Agricultural Science, 35 (1): 41-53.

Mazyad HM, El-Hammady M, Sabik A (1974). Occurrence of Cucumber mosaic virus on bean plants in Egypt. Proc. $2^{\text {nd }}$ Conf. Egypt. Phytopathol. Soc. Megahed AA, El-dougdoug KA, Othman BA, Lashin SM, Ibrahim MA, Sofy AR (2012). A new Egyptian satellite strain of cucumber mosaic cucumovirus. I. J. V. 8(3): 240-254.

Morsy FT (1979). Studies on some virus diseases of some Leguminous plant. M. Sc. Thesis. Fac. of Agric. Ain Shams Univ. Egypt.

Napier T (2009). Insect pests of cucurbit vegetables. Prime fact sheet No. 833, NSW Department of Primary Industries, Australia.

Palukaitis P, Garcia-Arenal F (2003). Cucumber mosaic virus. CMI/ AAB Description of Plant Viruses no. 400.

Pratap D, Kumar S, Snehi SK, Raj SK (2012). Biological and molecular characterization of Cucumber mosaic virus isolate causing shoestring disease of tomato in India which has closer affinity to European or East Asian isolates of CMV. Indian J. Virol., 23(1):57- 63.

Rao ALN, Francki RIB (1982). Distribution of determinants for symptom production and host range on the three RNA components of Cucumber mosaic virus. J. Gen. Virol., 61: 97-205.

Rasoulpour R, Izadpanah K (2008). Properties and taxonomic position of hoary cress strain of cucumber mosaic virus. J. Plant Pathol., 90 (1):97-102.
Saric A, Stefanac $Z$ (1988). The incidence and variation of Cucumber mosaic virus in four vegetable species in Croatia. Acta Bot. Croat., 47:7-13.

Sevik AM, Akcura C (2011). Occurrence of Cucumber mosaic virus infecting parsley (Petroselinum crispum) in Turkey. Not. Bot. Horti Agrobot. Cluj Napoca, 39(1): 30-33.

Sevik M, Balkaya A (2015). Seed transmissibility of viruses in winter squash landraces collected from the black sea region of Turkey. Plant Prot. Sci., 51: 195199.

Sharma YR, Chohan JS (1974). Transmission of cucumis viruses 1 and 3 through seeds of cucurbits. Indian Phytopathol., 26:596-598.

Shevchenko TP, Tymchyshyn OV, AIDalain E, Bysov AS, Budzanivska IG, Shevchenko OV, Polishchuk VP (2015). The first evidence of subgroup IB isolates of Cucumber mosaic virus in Ukraine. Biopolym. Cell, 31(1): 57-62.

Sulistyowati E, Neena Mitter N, Shanna BastiaanNet S, Roossinck MJ, Dietzgen RG (2004). Host range, symptom expression and RNA 3 sequence analyses of six Australian strains of Cucumber mosaic virus. Australas. Plant Path, 33:505-512.

Younes HA (1995). Studies on certain virus diseases affecting some vegetable crops under greenhouse conditions. Ph.D. Thesis, Faculty of Agriculture, Alexandria University, Egypt. 210 p.

Zitikaite I, Urbanaviciene L (2010). Detection of natural infection by Cucumber mosaic virus in vegetable crops. Biologija, 56(1-4):14-19.

Zitter TA, Murphy JF (2009). Cucumber mosaic virus. The Plant Health Instructor. DOI: 10.1094/PHI-I-2009-0518-01 


\title{
الملخص العربى
}

\section{Cucumber mosaic virus توصيف جزئى لعزلتين من فيروس موزيلك الخيار}

\author{
السبد السبد وجيه، محمد محسن زلط ، مها عادل كونه \\ قسم أمراض النبات، كلية الزراعة (الثاطبى)، جامعة الاسكندرية، الاسكندرية، مصر
}

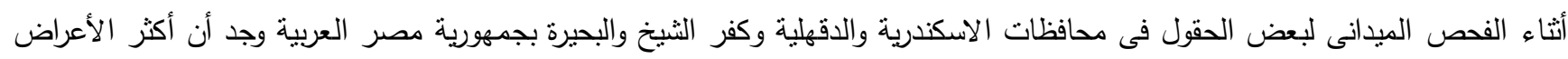

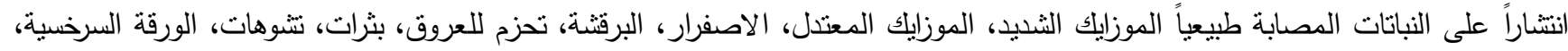

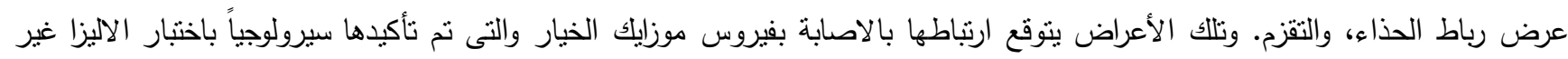

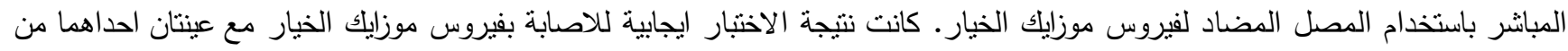

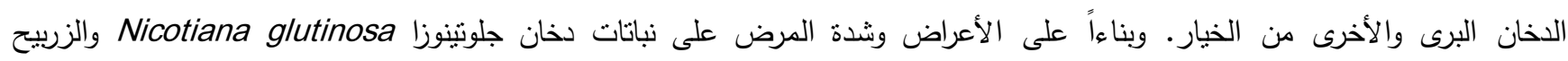
Chenopodium amaranticolor

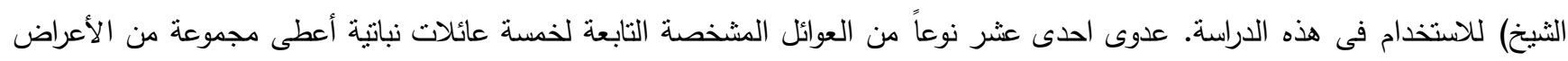
المميزة للاصابة بفيروس موزيك الخيار وكانت الأعراض شديدة فى حالة عزلة الاخان البرى مقارنة بعزلة الخيار ـ تم تأكيد تعريف العزلتين باختبار

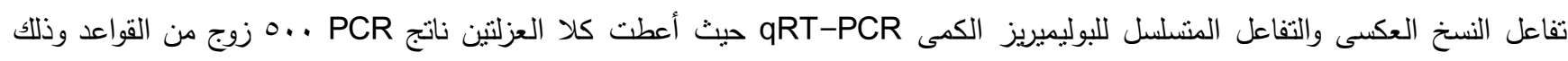

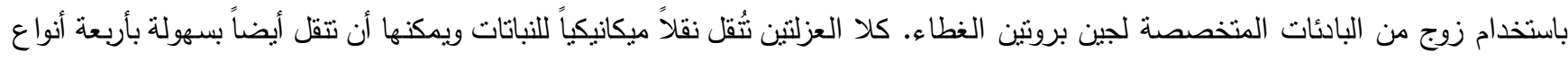

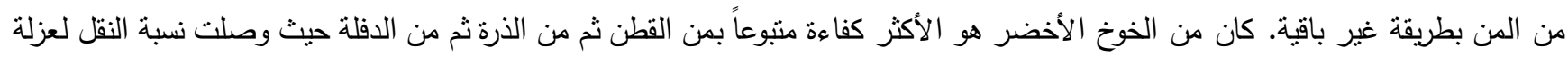

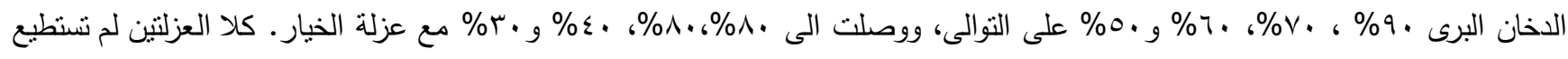

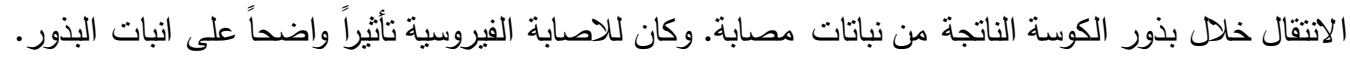

